\title{
ANALISIS METODE BINOMIAL DIPERCEPAT PADA PERHITUNGAN HARGA OPSI EROPA
}

\author{
Istiqomah, Abdul Aziz \\ Jurusan Matematika Universitas Islam Negeri Maulana Malik Ibrahim Malang \\ e-mail: thifa31@yahoo.com
}

\begin{abstract}
ABSTRAK
Model umum yang digunakan dalam perhitungan harga opsi Eropa adalah model Black Scholes. Kemudian ditemukan suatu metode baru yang merupakan aproksimasi dari model Black Scholes yaitu metode Binomial. Akan tetapi, perhitungan harga opsi Eropa menggunakan metode Binomial membutuhkan partisi waktu yang banyak untuk bisa mendekati model kontinu Black Scholes. Untuk mempercepat kekonvergenan aproksimasi harga opsi Eropa maka digunakan pengembangan dari model Binomial yaitu Binomial Dipercepat. Langkah yang dilakukan dalam metode Binomial Dipercepat adalah melakukan pemulusan kurva harga opsi yang disebut dengan Middle of Tree (MOT). Sebelum melakukan pemulusan kurva tersebut yang dilakukan terlebih dahulu adalah memisahkan partisi waktu yang digunakan yaitu partisi waktu ganjil dan genap. Asumsi yang digunakan pada MOT adalah dengan meletakkan harga ketentuan di tengah pohon binomial pada saat jatuh tempo. Dari asumsi tersebut didapatkan parameter $u$ dan $p$ yang akan digunakan dalam pemulusan kurva MOT. Dengan menggunakan parameter MOT tersebut diperoleh hasil dari harga opsi Eropa yang bisa mendekati harga kekonvergenan Black Scholes dengan partisi yang lebih sedikit dibandingkan dengan menggunakan metode Binomial.
\end{abstract}

Kata Kunci: Opsi Eropa, Binomial,Binomial Dipercepat, Middle of Tree (MOT)

\section{ABSTRACT}

A common model which is used the calculation of the price of European option is Black Scholes Model. Afterwards, there is a new model which in approximation of Black Scholes Model. This model is called as Binomial Model. But then, the calculation of the price of European Option with Binomial Model requires many iterations to approach the Continue Model of Black Scholes. The development of Binomial Model, Accelerated Binomial, is used accelerate the convergence of the approximation of European Option. On of steps in the Accelerated Binomial Method is the Middle of Tree (MOT). MOT is the smoothing of option price's curve. Before doing the smoothing of curve, the first step that must be done is separating the used time; odd and even time. The assumption that is used in MOT is placing the price provision among the binomial tree on the maturity time. The result the assumption $u$ and $p$ that will be applied in the smoothing of curve. The using of MOT parameter produces a result from the price of European Option that convergences to Black Scholes faster than using Binomial Model.

Keywords: European Option, Binomial, Accelerated Binomial, Middle of Tree (MOT)

\section{PENDAHULUAN}

Pada penelitian sebelumnya tentang perhitungan harga opsi Eropa menggunakan metode Binomial telah dijelaskan beberapa bentuk yang digunakan untuk menghitung harga opsi Eropa. Salah satu bentuk yang digunakan dalam perhitungan harga opsi Eropa adalah metode Binomial bentuk CRR.

Metode Binomial bentuk CRR ini untuk pertama kali dikembangkan secara simultan oleh Cox, Ross dan Rubinstein [1] serta Rendlemen dan Bartter [2] dengan mengasumsikan bahwa dalam suatu interval waktu, harga saham akan naik sebesar faktor $u$ (up) dan akan turun sebesar faktor d (down) karena dipengaruhi oleh faktor suku bunga. Selanjutnya CRR mempertimbangkan bahwa pergerakan harga saham juga dipengaruhi faktor volatilitas.

Semakin banyak partisi waktu yang digunakan pada metode Binomial CRR, maka harga opsi yang didapat akan semakin mendekati model kontinyu Black Scholes [3]. Akan tetapi, untuk mendapatkan harga opsi yang mendekati model kontinyu Black Scholes diperlukan waktu yang cukup lama karena dengan partisi waktu yang semakin banyak maka proses perhitungan harga opsi juga akan semakin banyak.

Setiap partisi waktu yang berubah pada metode Binomial CRR mengakibatkan keadaan strike price selalu berubah terhadap node pada waktu jatuh tempo. Ini menyebabkan terjadinya osilasi (naik turun) harga opsi terhadap partisi 
waktu, sehingga kekonvergenan terhadap Black Scholes sangat lambat [4]. Keadaan ini telah dibuktikan pada penelitian sebelumnya tentang perhitungan opsi Eropa dengan metode Binomial CRR. Jika menggunakan partisi waktu kecil maka harga saham pada waktu jatuh tempo yang diperoleh sangat kecil sehingga akan menyebabkan keadaan dimana antara opsi call dan opsi put tidak saling imbang.

Salah satu metode yang digunakan untuk mempercepat kekonvergenan harga opsi metode Binomial CRR terhadap harga opsi metode Black Scholes adalah dengan melakukan pemulusan kurva terhadap pohon Binomial CRR atau biasa disebut dengan Middle of Tree (MOT). Dengan melakukan pemulusan kurva Binomial CRR maka peneliti akan mendapat harga saham pada waktu jatuh tempo yang lebih besar dari metode Binomial CRR. Dengan nilai harga saham pada waktu jatuh tempo yang lebih besar maka dengan partisi waktu berapapun akan didapatkan nilai $K$ yang selalu ada di tengah pohon Binomial pada saat jatuh tempo. Hal ini menyebabkan nilai opsi call ataupun put selalu tidak nol sehingga kedua opsi tersebut dapat memiliki peluang untuk mendapatkan untung.

\section{TINJAUAN TEORI}

\section{Binomial}

\section{Definisi 2.1.1}

Eksperimen Binomial: Suatu eksperimen dinamakan eksperimen binomial bila dan hanya bila eksperimen yang bersangkutan terdiri dari percobaan-percobaan binomial.

Anggaplah $p$ adalah probabilitas bahwa suatu kejadian akan terjadi dalam suatu percobaan tunggal sembarang (disebut peluang keberhasilan), maka $q=1-p$ adalah probabilitas bahwa suatu kejadian akan gagal dalam setiap satu percobaan (disebut peluang kegagalan). Probabilitas bahwa suatu kejadian akan terjadi tepat $x$ kali dalam $n$ percobaan (artinya, keberhasilan-keberhasilan (sukses) dan $n-x$ kegagalan akan terjadi) ditentukan oleh fungsi probabilitas

$f(x)=P(X=x)=\left(\begin{array}{l}n \\ x\end{array}\right) p^{x} q^{n-x}=\frac{n !}{x !(n-x) !} p^{x} q^{n-x}$

dimana variabel acak $X$ melambangkan jumlah keberhasilan dalam $n$ percobaan dan $x=0,1, \ldots, n$.

\section{Opsi}

Opsi (Option) adalah sebuah hak atau suatu kontrak antara writer (penjual) dan holder (pembeli) pemegang opsi yang memberikan hak, kepada holder (pemegang option) untuk membeli atau menjual suatu aset pokok (underlying asset) pada suatu tanggal tertentu untuk suatu harga tertentu. Ada dua tipe dasar opsi yaitu call dan put. Opsi call adalah hak untuk membeli sejumlah tertentu suatu underlying asset dengan harga sebesar strike price, pada waktu jatuh tempo (maturity date). Sedangkan opsi put adalah hak untuk menjual sejumlah tertentu suatu underlying asset dengan harga sebesar strike price, pada waktu jatuh tempo (maturity date) [5].

Kontrak opsi adalah suatu perjanjian yang memberikan hak kepada holder untuk membeli suatu underlying asset. Pada tingkat harga tertentu (striking price) pada saat tanggal tertentu (maturity date). Seorang holder suatu opsi harus membuat suatu keputusan apa yang akan ia lakukan terhadap tanggungan kontrak hak opsi ini. Keputusannya akan ditentukan pada situasi pasar, dan tipe opsi ini. Misalkan pada call opsi Eropa, dia dapat mengabaikan opsi ini bila harga saham (stock price) di pasar pada waktu jatuh tempo (maturity date) lebih rendah dari pada harga call opsi (strike price), karena tidak dapat memberikan keuntungan. Ia lebih baik membeli saham serupa di pasar dengan harga yang lebih rendah dari pada membelinya pada writer dengan harga strike price.

Menurut seydel [3] jika $S_{T}$ adalah harga saham di pasar pada waktu $T$ dan $K$ adalah strike price maka keuntungan atau nilai payoff untuk kedua jenis opsi di atas diberikan oleh: untuk opsi call

$$
C=\max \left(S_{T}-K\right)=\left(S_{T}-K, 0\right)^{+}
$$

Sedangkan untuk opsi put diberikan oleh

$$
P=\max \left(K-S_{T}\right)=\left(K-S_{T}, 0\right)^{+}
$$

Writer memperoleh keuntungan dari biaya atau harga opsi dari holder, baik holder melaksanakan haknya maupun tidak melaksanakan haknya. Holder (pemegang opsi) akan mendapatkan untung, jika menggunakan hak opsinya, dari nilai opsi yang diperoleh dari selisih harga saham pada pasar bebas dengan harga saham pada opsi, yang diistilahkan dengan payoff, $V$, setelah dikurangi dengan harga opsi (option price), yang diistilahkan dengan profit atau keuntungan. Keuntungan atau kerugian yang diperoleh holder atau pemegang opsi call pada waktu $T$ :

$$
\begin{aligned}
\text { Profit } & =\text { payoff }- \text { harga option } \\
& =V_{c}-C=\max \left(K-S_{T}, 0\right)-C
\end{aligned}
$$

sebaliknya, bagi pemegang opsi put akan mendapatkan keuntungan atau kerugian:

Profit $=$ payoff - harga option 


$$
=V_{p}-P=\max \left(K-S_{T}, 0\right)-P
$$

Artinya, jika profit bernilai positif maka pemegang opsi mendapatkan keuntungan, dan sebaliknya jika negatif merupakan kerugian yang maksimal sebesar harga opsi. Berikut ini adalah gambar kurva fungsi payoff dan profit untuk opsi call dan opsi put. Profit diperoleh dari pengurangan harga transaksi pada saat membeli opsi terhadap nilai payoff yang diperoleh [6].

\section{Metode Binomial Eropa}

Pada kenyataannya harga saham di pasar bebas akan selalu berubah naik atau turun dengan perubahan waktu. Kemungkinan dua arah perubahan inilah yang digunakan sebagai dasar model binomial. Misalkan harga saham saat pembuatan opsi, adalah $S_{0}$ naik dengan peluang $p$ menjadi $S_{u}$ atau akan turun dengan peluang $q$ menjadi $S_{d}$. Sehingga nilai opsi pada saat pembuatan opsi, adalah $V_{0}$ dan pada saat naik menjadi $U$ atau akan turun menjadi $D$. Permodelan matematika diharapkan dapat membantu untuk memahami keadaan sekarang dan prediksinya pada waktu yang akan datang. Oleh karena itu, agar model binomial ini dapat berhasil dengan lebih baik maka harus sesuai dengan keadaan dunia nyata. Masalah yang dihadapi sekarang adalah bagaimana kita memilih $p, u$, dan $d$ sedemikian hingga model binomial ini mendekati pada keadaan dunia nyata [6].

Memulai dengan diskritisasi, yaitu menjadikan waktu kontinu $t$ menjadi diskrit dengan menggantikan $t$ oleh waktu yang sama lamanya katakanlah $t_{i}$. bidang $(S, t)$ diwakili oleh garis-garis lurus paralel dengan jarak $\Delta t$. Mengganti nilai-nilai kontinu $S_{i}$ sepanjang paralel $t=t_{i}$ dengan nilai-nilai diskrit $S_{\mathrm{ji}}$, untuk semua $i$ dan $j$ yang sesuai. Untuk lebih memahami lihat gambar 1. Gambar ini menunjukkan sebuah hubungan grid, katakanlah perubahan dari $t$ ke $t+\Delta t$, atau dari $t_{i}$ ke $t_{i+1}$.

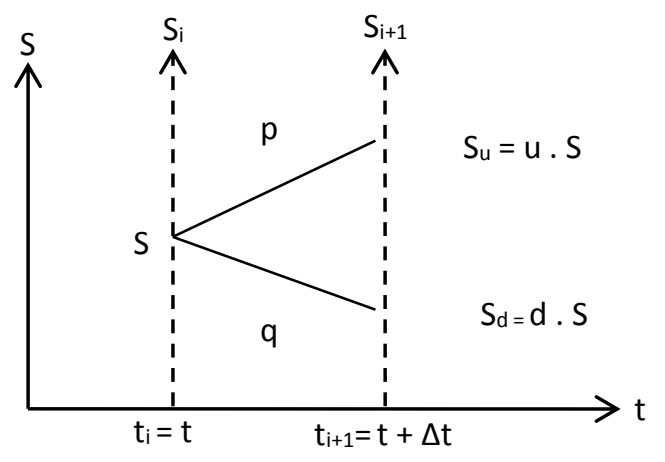

Gambar 1 Prinsip Metode Binomial

Misalkan digunakan notasi sebagai berikut: $M$ = banyaknya selang waktu $i=$ indeks waktu, $t_{i}=$ waktu ke $i$

$j=$ indeks kemungkinan harga saham dengan:

$$
\begin{aligned}
& \quad \quad \quad M \\
& t_{i}: i \square \quad i=0,1,2,3, \ldots, M \\
& j=0,1,2,3, \ldots, i \\
& S_{i}: S\left(t_{i}\right)
\end{aligned}
$$

Asumsi-asumsi yang digunakan dalam permodelan ini adalah:

1. Harga $S$, sebagai harga awal, selama setiap periode waktu $\Delta t$ hanya dapat berubah dalam dua kemungkinan yaitu naik menjadi $S_{u}$ atau turun menjadi $S_{d}$ dengan $0<d<u$. Di $\operatorname{sini} u$ dan $d$ masing-masing merupakan faktor perubahan naik dan turun yang konstan untuk setiap $\Delta t$.

2. Peluang perubahan naik adalah $p, \mathrm{P}($ naik $)=p$. Sehingga $\mathrm{P}($ turun $)=q=(1-p)$.

3. Ekspektasi harga saham secara acak kontinu, dengan suku bunga bebas resiko $(r)$, dari harga saham ke $i$ pada waktu ke $i$ menjadi harga saham ke $i+1$ pada waktu ke $i+1$ adalah:

$$
E\left(S_{i+1}\right)=S_{i} \cdot e^{r \Delta t}
$$

4. Tidak ada pembayaran dividen $(\delta)$ selama periode waktu tersebut.

Skema (tree) untuk fluktuasi harga saham secara diskrit dapat dibangun menggunakan model binomial. Sehingga secara umum harga saham pada saat $t=t_{i}$ terdapat $i+1$ kemungkinan dengan rumus umum:

$$
\begin{array}{r}
S_{j i}=S_{0} u^{j} d^{i-j}, i=0,1, \ldots, M \quad j=0,1, \ldots i . \\
\operatorname{dan} i \geq j
\end{array}
$$

\section{PEMBAHASAN}

Berdasarkan konstruksi tentang metode binomial untuk perhitungan harga opsi Eropa, yang didasarkan pada perhitungan harga saham. Harga saham pada waktu tertentu sangat diperlukan oleh holder (pembeli) dan writer (penjual) untuk memprediksi nilai opsi. Menghitung harga opsi Eropa dan opsi Asia Eropa terlebih dulu mencari payoff atau nilai opsi. Mencari nilai opsi Eropa dan opsi Asia Eropa, pada kontrak opsi yang dilakukan holder dan writer, saat pertama kali perjanjian holder (pembeli) harus menentukan opsi call (hak untuk membeli) atau opsi put (hak untuk menjual), pada kontrak opsi Eropa dan opsi Asia Eropa diketahui harga saham awal $\left(S_{0}\right)$ dan menentukan harga saham perjanjian (strike 
price, $K$ ) dalam waktu jatuh tempo (maturity date, $T$ ).

Menentukan harga saham pada waktu jatuh tempo membutuhkan harga saham awal dengan metode binomial. Harga saham di pasar bebas pada waktu tertentu yang akan datang, tidak dapat dipastikan. Harga saham pasar bebas kenyataannya selalu mengalami perubahan naik atau turun setiap detiknya atau dengan perubahan waktu. Kemungkinan dua arah perubahan inilah yang digunakan sebagai dasar metode binomial. Pada metode binomial, diketahui harga saham awal, untuk mengetahui harga saham sampai dengan jatuh tempo menggunakan persamaan (4).

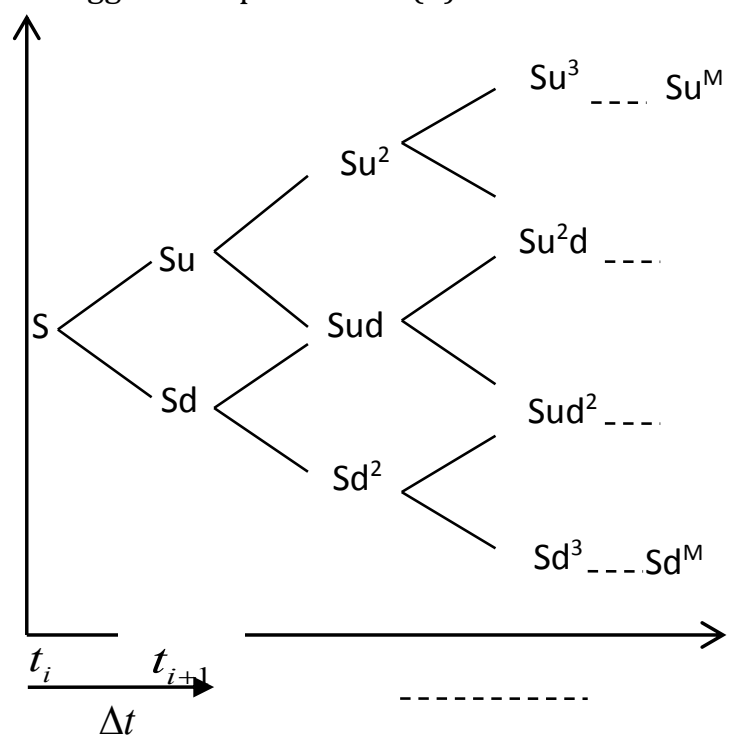

Gambar 2. Skema Fluktuasi Harga Saham Secara Binomial

dari ekspektasi di atas didapatkan rumus diskrit harga saham pada waktu $t=M$ sebagai berikut:

$$
E\left(S_{M}\right)=(p u+q d)^{M} S_{0}
$$

Persamaan (4) adalah tidak rekursif, artinya perhitungan yang memerlukan waktu relatif lama, sehingga perlu adanya bentuk rekursif yang diperoleh sebagai berikut, dengan bantuan persamaan

$$
E\left(S_{M}\right)=S_{0} e^{r \Delta t}
$$

untuk menghitung harga saham awal dari harga saham jatuh tempo menggunakan diskon $e^{-r \Delta t}$ dari persamaan (3) dengan rumus:

$$
\begin{aligned}
& S_{0}=e^{-r \Delta t} E\left(S_{1}\right) \\
& S_{j i}=e^{-r \Delta t}\left(p S_{j+1, i+1}+q S_{j, i+1}\right)
\end{aligned}
$$

dan untuk mengetahui harga saham sebelumnya menggunakan persamaan (7). Dari langkahlangkah ini, dapat menemukan dari harga opsi awal sampai jatuh tempo, terdapat model untuk mencari harga opsi yaitu model opsi Eropa yang di bandingkan dengan model Black-Scholes.

\section{Perhitungan Harga Opsi Eropa}

Model yang pertama menggunakan opsi Eropa. Setelah menemukan harga saham waktu jatuh tempo, dari itu dapat memperoleh nilai opsi Eropa. Sebelum menghitung nilai opsi, menentukan jenis opsi terlebih dahulu, yaitu opsi call atau opsi put. Menghitung nilai opsi call (call payoff) yaitu

$$
V_{j M}=\max \left(S_{j M}-K, 0\right)
$$

terdapat beberapa nilai $j=0,1,2, \ldots, i$ dan $i$ $=0,1,2, \ldots, M$.

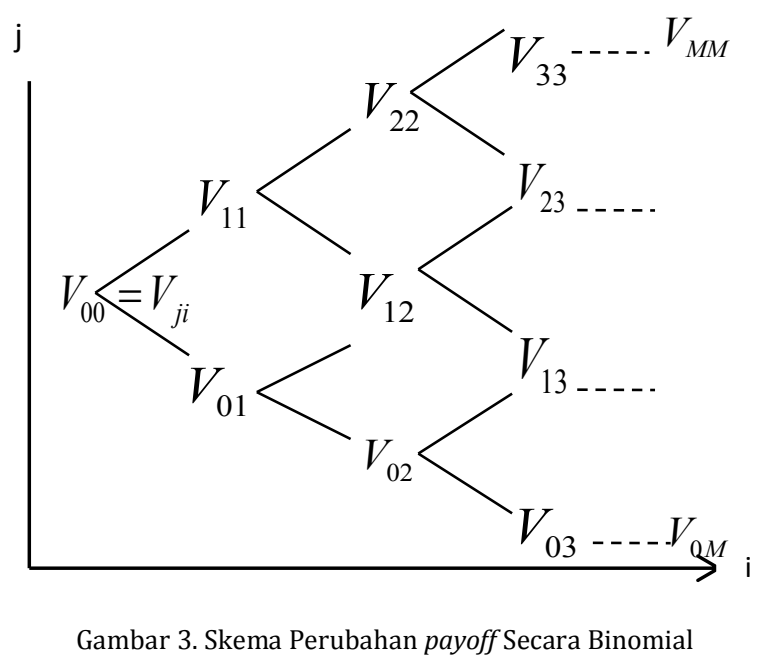

Dari beberapa nilai opsi ini diperoleh secara binomial mundur harga opsi awal,

$$
V_{0}=e^{-r \Delta t}\left(p V_{j+1, i+1}+q V_{j, i+1}\right)
$$

dan untuk menghitung nilai opsi put (put payoff) yaitu

$$
V_{j M}=\max \left(K-S_{j M}, 0\right)
$$

terdapat beberapa nilai $j=0,1,2, \ldots, i$ dan $i$ $=0,1,2, \ldots, M$. Dari beberapa nilai opsi ini diperoleh secara binomial mundur harga opsi awal,

$$
V_{0}=e^{-r \Delta t}\left(p V_{j+1, i+1}+q V_{j, i+1}\right)
$$

Supaya model binomial ini mendekati pada keadaan dunia nyata, maka harus mencari nilai parameter $u, d$ dan $p$.

\section{Parameter-parameter $u, d$, dan $p$}

Metode dengan asumsi $u . d=1$. Untuk menentukan tiga parameter yang belum diketahui, $u, d$, dan $p$, diperlukan tiga persamaan, yaitu:

1) Menyamakan ekspektasi harga saham model diskrit dengan model kontinu 
2) Menyamakan variansi model diskrit dengan model kontinu

3) Menyamakan $u \cdot d=1$

Persamaan pertama menyamakan ekspektasi harga saham model diskrit dengan model kontinu yaitu menggunakan persamaan (5) dan persamaan (6) pada waktu jatuh tempo $t_{M}$. sehingga diperoleh nilai untuk $u, d$ dan $p$ yaitu:

$u=\frac{\beta+\sqrt{\beta^{2}-4}}{2}, d=\frac{1}{u}, p=\frac{e^{r \Delta t}-d}{u-d}$

dengan

$$
\beta=e^{-r \Delta t}+e^{\left(r+\sigma^{2}\right) \Delta t}
$$

\section{Metode Binomial Dipercepat}

Pada metode Binomial Dipercepat ini konsep yang digunakan adalah konsep pemulusan kurva harga opsi Eropa yang disebut dengan Middle of Tree (MOT). Middle of Tree (MOT) adalah pemulusan kurva dengan meletakkan harga $K$ di tengah pohon Binomial pada saat waktu jatuh tempo sehingga harga $K$ selalu tetap terhadap node di setiap nilai $M$ yang berubah. Untuk menghilangkan osilasi pada harga opsi Eropa menggunakan metode Binomial CRR, partisi waktu dipisahkan menjadi $M$ ganjil dan $M$ genap [4].

Harga $K$ selalu terletak di tengah pohon Binomial pada saat waktu jatuh tempo dengan cara merubah parameter $u$ dan $d$. Oleh karena harga $K$ harus terletak di tengah pohon Binomial pada saat jatuh tempo, maka

$$
S_{0} u d=S_{0} u^{2} d^{2}=S_{0} u^{3} d^{3}=\cdots \quad l^{i-j}=K
$$

dengan $i=1,2, \cdots$

Pada saat jatuh tempo, harga $K$ harus terletak di tengah noktah-noktah pohon Binomial, akibatnya

$$
S_{0}(u d)^{\frac{M}{2}}=K
$$

Pada metode Binomial CRR, harga saham akan naik atau turun bergantung pada parameter $u$ dan $d$ sesuai dengan rumus yaitu

$$
u=e^{\sigma \sqrt{\Delta t}} \text { dan } d=e^{-\sigma \sqrt{\Delta t}}
$$

Sedangkan parameter $u$ dan $d$ pada metode Binomial Dipercepat diubah dengan menambahkan variable $C_{1}$ dan $C_{2}$ pada eksponensial parameter $u$ dan $d$. Penambahan variabel $C_{1}$ dan $C_{2}$ membuat harga node saham akan bergerak sehingga keadaan $K$ selalu berada di tengah-tengah jumlah node pohon Binomial pada saat waktu jatuh tempo sehingga didapatkan parameter $u$ dan $d$ sebagai berikut:

$$
u=e^{\sigma \sqrt{\Delta t}+C_{1}}, d=e^{-\sigma \sqrt{\Delta t}+C_{2}}
$$

Dengan mensubtitusikan persamaan (13) dan (14) dan dengan melakukan pemilihan nilai $C_{1}$ dan $C_{2}$ didapatkan

$$
C_{1}=C_{2}=\frac{\ln \left(\frac{K}{S_{0}}\right)}{M}
$$

Dan dengan mensubtitusikan persamaan (13) ke persamaan (14) didapatkan parameter $u$ dan $d$ sebagai berikut:

$$
u=e^{\sigma \sqrt{\Delta t}+\frac{\ln \left(\frac{K}{S_{0}}\right)}{M}}, d=e^{-\sigma \sqrt{\Delta t}+\frac{\ln \left(\frac{K}{S_{0}}\right)}{M}}
$$

\section{Simulasi Grafik}

Ilustrasi yang dgunakan untuk menentukan harga opsi call dan harga opsi put dari model opsi Eropa dengan perbandingan model Black Scholes dan model opsi Eropa akan diberikan tiga contoh simulasi sebagai berikut. Warna hijau menunjukkan harga opsi genap, warna merah menunjukkan harga opsi ganjil warna biru menunjukkan harga black Scholes, dan warna biru menunjukkan opsi Asia Eropa.

\subsection{Harga Saham Lebih Besar dari Harga Ketentuan}

Untuk grafik call opsi

$S_{0}=50, K=43, r=0.15, \sigma=0.24, M=146$

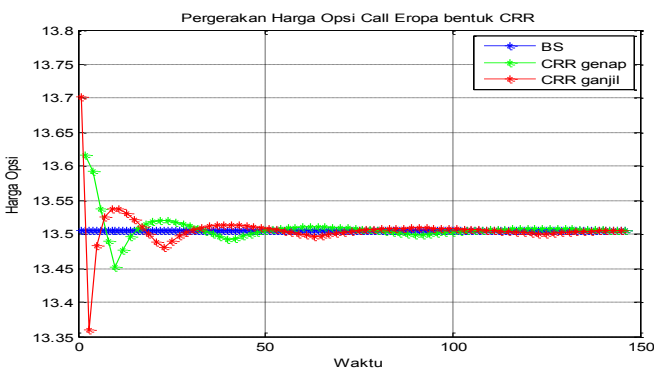

Gambar 4. Grafik hasil Simulasi Harga Opsi Call dengan pemisahan partisi waktu M

Dari pemisahan partisi ini didapatkan hasil yang yang sama dengan hasil sebelumnya hanya dibedakan partisi $M$ ganjil dan $M$ genap. Dari hasil simulasi opsi call menggunakan metode Binomial CRR didapatkan bahwa holder (pemegang opsi) harus membayar sebesar 13.5056 kepada writer (penulis opsi) dengan acuan perhitungan menggunakan Black Scholes. Untuk hasil dari MOT adalah sebagai berikut: 


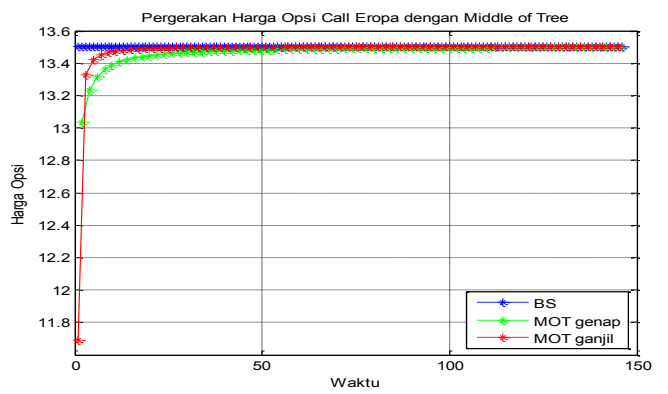

Gambar 5. Grafik hasil Simulasi Harga Opsi Call dengan MOT

Dari grafik hasil pemulusan dapat dilihat bahwa harga opsi Eropa menggunakan Binomial Dipercepat sudah dapat mendekati harga Black Scholes dengan partisi 101. Kekonvergenan ini lebih cepat dibandingkan dengan kekonvergenan menggunakan metode Binomial CRR di mana harga opsi Eropa yang didapat dari metode Binomial Dipercepat pada partisi waktu 101 baru dapat didapat oleh metode Binomial CRR pada partisi waktu 146.

Untuk grafik put opsi

$$
S_{0}=50, K=43, r=0.15, \sigma=0.24, M=146
$$

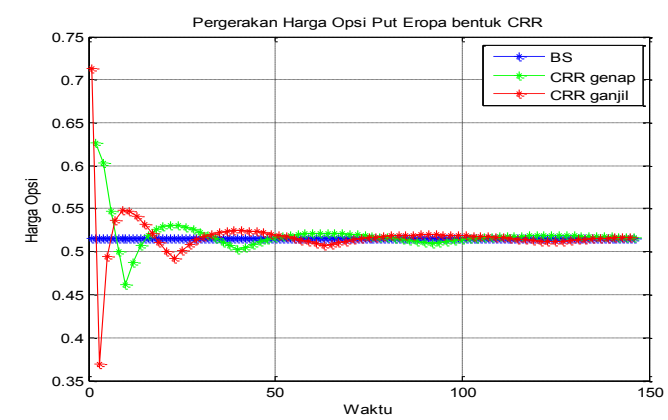

Gambar 6. Grafik hasil Simulasi Harga Opsi Put dengan pemisahan partisi waktu M

Dari pemisahan partisi ini didapatkan hasil yang yang sama dengan hasil sebelumnya hanya dibedakan partisi $M$ ganjil dan $M$ genap. Dari hasil simulasi opsi put menggunakan metode Binomial CRR didapatkan bahwa holder (pemegang opsi) harus membayar sebesar 0.5160 kepada writer (penulis opsi) dengan acuan perhitungan menggunakan Black Scholes. Untuk hasil dari MOT adalah sebagai berikut:

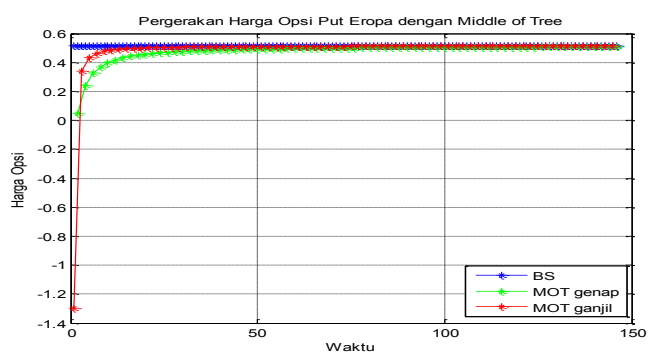

Gambar 7. Grafik hasil Simulasi Harga Opsi Put dengan MOT

Dari grafik hasil pemulusan dapat dilihat bahwa harga opsi Eropa menggunakan Binomial Dipercepat sudah dapat mendekati harga Black Scholes dengan partisi 101. Kekonvergenan ini lebih cepat dibandingkan dengan kekonvergenan menggunakan metode Binomial CRR di mana harga opsi Eropa yang didapat dari metode Binomial Dipercepat pada partisi waktu 101 baru dapat didapat oleh metode Binomial CRR pada partisi waktu 146.

\subsection{Harga Saham sama dengan Harga Ketentuan}

Untuk grafik call opsi

$S_{0}=50, K=50, r=0.15, \sigma=0.24, M=146$

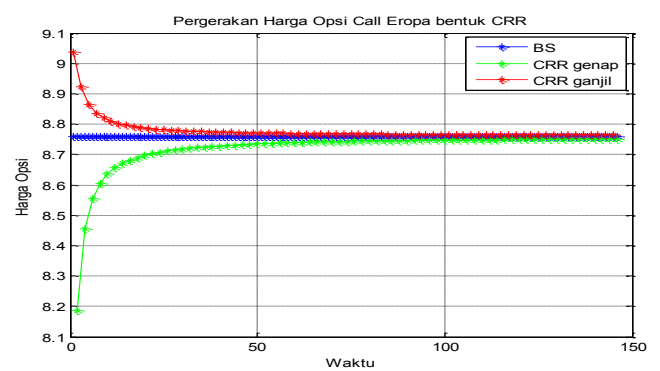

Gambar 8. Grafik hasil Simulasi Harga Opsi Call dengan pemisahan partisi waktu M

Dari pemisahan partisi ini didapatkan hasil yang yang sama dengan hasil sebelumnya hanya dibedakan partisi $M$ ganjil dan $M$ genap. Dari hasil simulasi opsi put menggunakan metode Binomial CRR didapatkan bahwa holder (pemegang opsi) harus membayar sebesar 8.7602 kepada writer (penulis opsi) dengan acuan perhitungan menggunakan Black Scholes. Untuk hasil dari MOT adalah sebagai berikut:

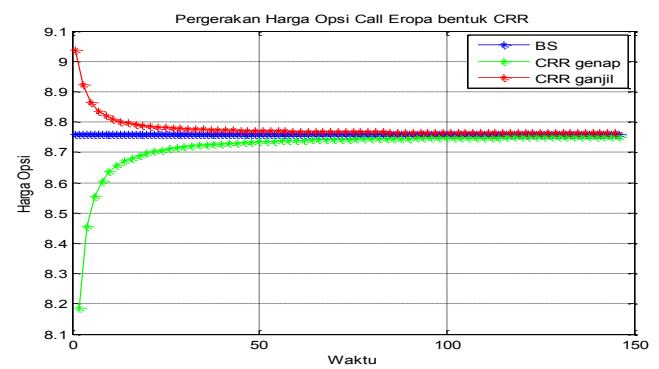

Gambar 9. Grafik hasil Simulasi Harga Opsi Call dengan MOT

Grafik yang didapatkan dari pemulusan kurva ini adalah sama dengan grafik dari binomial CRR sebelumnya dengan pemisahan partisi waktu. Harga opsi awal yang didapat adalah 9.0378 dan pada waktu ke-146 harga opsi call Eropa yang didapatkan adalah 8.7515 
dan harga Black Scholes adalah 8.7602. Sehingga, hasil yang diperoleh sama dengan hasil yang diperoleh pada Binomial CRR dengan pemisahan partisi waktu

Untuk grafik put opsi

$$
S_{0}=50, K=50, r=0.15, \sigma=0.24, M=146
$$

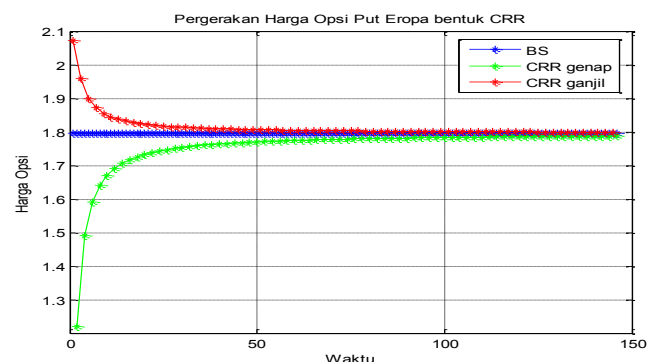

Gambar 10. Grafik hasil Simulasi Harga Opsi Put dengan pemisahan partisi waktu M

Dari pemisahan partisi ini didapatkan hasil yang yang sama dengan hasil sebelumnya hanya dibedakan partisi $M$ ganjil dan $M$ genap. Dari hasil simulasi opsi put menggunakan metode Binomial CRR didapatkan bahwa holder (pemegang opsi) harus membayar sebesar 1.7956 kepada writer (penulis opsi) dengan acuan perhitungan menggunakan Black Scholes. Pergerakan harga opsi put Eropa dengan menggunakan metode MOT sama dengan pergerakan harga opsi call Eropa dengan menggunakan metode MOT yaitu grafiknya sama dengan hasil perhitungan Binomial CRR dengan pemisahan partisi waktu. Sehingga, untuk mengetahui pergerakan harga opsi put Eropa dengan MOT dapat dilihat pada pergerakan harga opsi put Eropa menggunakan Binomial CRR dengan pemisahan partisi waktu.

\subsection{Harga Saham kurang dari Harga Ketentuan}

Untuk grafik call opsi

$S_{0}=50, K=57, r=0.15, \sigma=0.24, M=146$

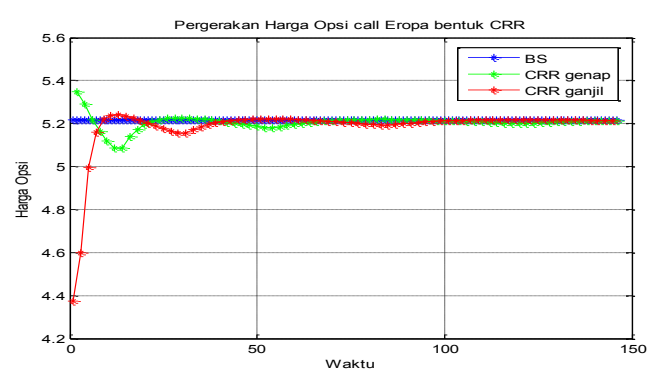

Gambar 11. Grafik hasil Simulasi Harga Opsi Call dengan pemisahan partisi waktu M

Dari pemisahan partisi ini didapatkan hasil yang yang sama dengan hasil sebelumnya hanya dibedakan partisi $M$ ganjil dan $M$ genap. Dari hasil simulasi opsi put menggunakan metode Binomial CRR didapatkan bahwa holder (pemegang opsi) harus membayar sebesar 5.2155 kepada writer (penulis opsi) dengan acuan perhitungan menggunakan Black Scholes. Untuk hasil dari MOT adalah sebagai berikut:

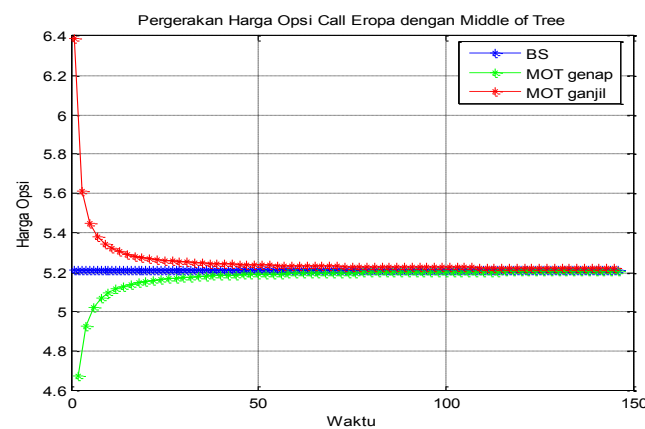

Gambar 12. Grafik hasil Simulasi Harga Opsi Call dengan MOT

Dari grafik hasil pemulusan dapat dilihat bahwa harga opsi Eropa menggunakan Binomial Dipercepat sudah dapat mendekati harga Black Scholes dengan partisi 101. Kekonvergenan ini lebih cepat dibandingkan dengan kekonvergenan menggunakan metode Binomial CRR di mana harga opsi Eropa yang didapat dari metode Binomial Dipercepat pada partisi waktu 101 baru dapat didapat oleh metode Binomial CRR pada partisi waktu 146.

Untuk grafik put opsi

$S_{0}=50, K=57, r=0.15, \sigma=0.24, M=146$

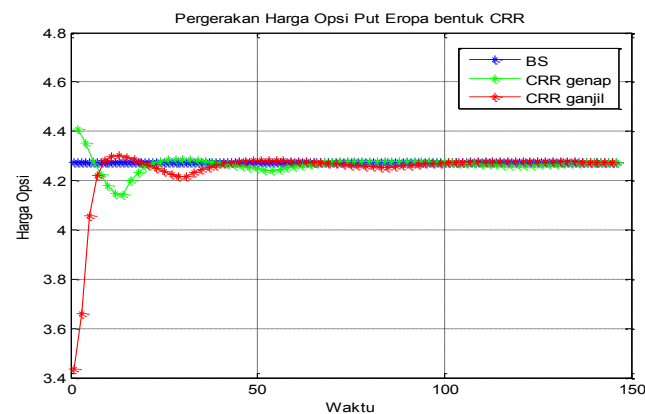

Gambar 13. Grafik hasil Simulasi Harga Opsi Put dengan pemisahan partisi waktu M

Dari pemisahan partisi ini didapatkan hasil yang yang sama dengan hasil sebelumnya hanya dibedakan partisi $M$ ganjil dan $M$ genap. Dari hasil simulasi opsi put menggunakan metode Binomial CRR didapatkan bahwa holder (pemegang opsi) harus membayar sebesar 4.2758 kepada writer (penulis opsi) dengan acuan perhitungan menggunakan Black Scholes. Untuk hasil dari MOT adalah sebagai berikut: 


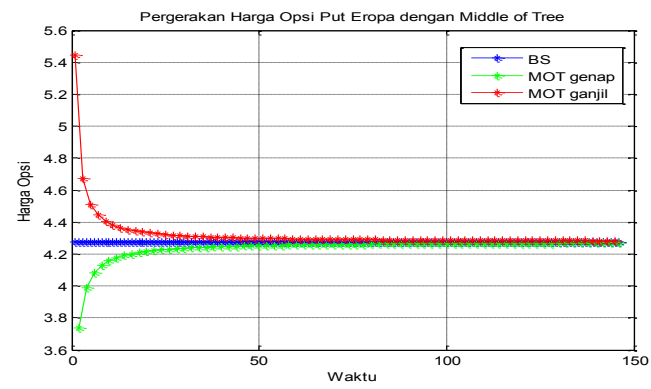

Gambar 14. Grafik hasil Simulasi Harga Opsi Put dengan MOT

Dari grafik hasil pemulusan dapat dilihat bahwa harga opsi Eropa menggunakan Binomial Dipercepat sudah dapat mendekati harga Black Scholes dengan partisi 101. Kekonvergenan ini lebih cepat dibandingkan dengan kekonvergenan menggunakan metode Binomial CRR di mana harga opsi Eropa yang didapat dari metode Binomial Dipercepat pada partisi waktu 101 baru dapat didapat oleh metode Binomial CRR pada partisi waktu 146 .

\section{PENUTUP}

Semakin banyak partisi waktu yang digunakan maka aproksimasi harga opsi akan semakin lambat untuk menuju kekonvergenan terhadap Black Scholes. Untuk mempercepat kekonvergenan aproksimasi harga opsi Eropa maka digunakan pengembangan dari model Binomial yaitu Binomial Dipercepat. Langkah yang dilakukan dalam metode Binomial Dipercepat adalah melakukan pemulusan kurva harga opsi yang disebut dengan Middle of Tree (MOT). Akan tetapi, sebelum melakukan pemulusan kurva tersebut yang dilakukan terlebih dahulu adalah memisahkan partisi waktu yang digunakan yaitu partisi waktu ganjil dan genap. Dengan menggunakan parameter MOT tersebut diperoleh hasil dari harga opsi Eropa yang bisa mendekati harga kekonvergenan Black Scholes dengan partisi yang lebih sedikit dibandingkan dengan menggunakan metode Binomial.

\section{Saran}

genelitian selanjutnya, disarankan untuk menggunakan metode Binomial Dipercepat pada perhitungan harga opsi Asia Eropa, opsi Amerika ataupun opsi Asia Amerika. Bisa juga dikembangkan metode lain untuk mempercepat perhitungan harga opsi selain menggunakan pemulusan kurva MOT.

\section{BIBLIOGRAPHY}

[1]

S. Ross, An introduction to mathematical finance: options and other topics, vol. 36. Cambridge university press Cambridge, 1999.

[2] R. J. Rendleman and B. J. Bartter, "Two State Option Pricing," J. Finance, vol. 34, no. 5, pp. 1093-1110, 1979.

[3] R. Seydel and R. Seydel, Tools for computational finance, vol. 4. Springer, 2002.

[4] T. R. Klassen, "Simple, fast, and flexible pricing of Asian options," J. Comput. Financ., vol. 4, no. 3, pp. 89-124, 2001.

[5] Z. Bodie, Essentials of investments.

[6] A. Aziz, "Empat Bentuk Nilai Parameterparameter $u, d$, dan $p$ dalam Binomial Harga Saham," 2004. [Online]. Available: http://blog.uinmalang.ac.id/abdulaziz/files/2010/08/A bdul-Aziz-Empat-Bentuk-Solusi-ModelBinomial-fulltext_1.pdf. [Accessed: 06Nov-2014]. 